International Journal of Current Microbiology and Applied Sciences

ISSN: 2319-7706 Volume 6 Number 8 (2017) pp. 3384-3387

Journal homepage: http://www.ijcmas.com

Original Research Article

https://doi.org/10.20546/ijcmas.2017.608.404

\title{
Effect of Various Dosages of Castor (Racinius communis) Leaves on Okra (Abelmoschus esculentus) Under Screen House Conditions
}

\author{
Gurpreet Singh*, Neeraj, K.K. Verma and Sewak Ram \\ Department of Nematology, CCS HAU, Hisar-125004, India \\ *Corresponding author
}

A B S T R A C T

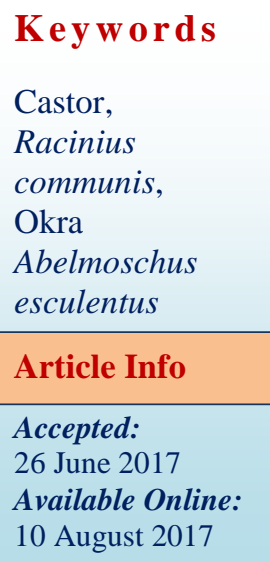

\section{Introduction}

Okra (Abelmoschus esculentus) or ladies finger is important vegetable of the tropical countries including India. Largest area and production is in India followed by Nigeria. The total area under okra in India is $0.49 \mathrm{mha}$ with production of 5552 thousand tons.

The young tender fruits of okra are cooked in curries, stewed and used as soups. It is a rich source of many nutrients. A half cup of okra contains calories 25 , dietary fiber $2 \mathrm{~g}$, protein $1.5 \mathrm{~g}$, carbohydrates $5.8 \mathrm{~g}$, vitamin A $460 \mathrm{IU}$, vitamin C $13 \mathrm{mg}$, folic acid $36.5 \mu \mathrm{g}$, calcium $50 \mathrm{mg}$, iron $0.4 \mathrm{mg}$, potassium $25 \mathrm{mg}$, magnesium 46mg.
Crop is subjected to attack by many insects and pathogens including fungi, viruses, mycoplasmas and nematodes (Srivastava et al., 2012). The most widespread and economically important are the root-knot nematodes (Meloidogyne spp.). Their life cycle is completed in 25 days at $27{ }^{\circ} \mathrm{C}$. The short life cycle enables root-knot nematode populations to survive well in the presence of a suitable host and their populations build up to a maximum as crops reach maturity. In susceptible plants, the nematode population build up to a maximum usually as crop reaches maturity (Shurtleff and Averre, 2000) and in some cases the plants die even before 
reaching maturity (Singh and Khurma, 2007). Root-knot nematode, Meloidogyne incognita causes $14.1 \%$ yield losses in okra, this is equivalent to 480 million rupees (Jain et al., 2007). Since castor is abundant in the study area, there is the need to explore its potential for the management of root-knot nematode under local conditions. This study therefore sought to evaluate the efficacy of different dosages of chopped castor leaves against rootknot nematodes and determine its effect on growth characteristics and yield of okra plants.

\section{Materials and Methods}

A pot experiment was conducted at Chaudhary Charan Singh Haryana Agricultural University, Hisar in earthern pots of $15 \mathrm{~cm}$ diameter. Pots were filled with sterilized soil (1 kg/pot) along with chopped fresh leaves of Racinius communis with different dosages viz, $\mathrm{T}_{1^{-}}$5g/pot, $\mathrm{T}_{2}-10$ g/pot, $\mathrm{T}_{3}-15 \mathrm{~g} / \mathrm{pot}, \mathrm{T}_{4}-20 \mathrm{~g} / \mathrm{pot}, \mathrm{T}_{5}-25 \mathrm{~g} / \mathrm{pot}$ and $\mathrm{T}_{6}$-untreated check. Thus, 6 treatments were tried in Completely Randomized Design keeping 4 replications.

Proper moisture was ensured for decomposition of leaves. After 7 days of waiting period, 5-7 seeds of okra cv. Varsha uphar were sown/pot. 800j2/pot of Meloidogyne indica were inoculated after 17 days of sowing of seed. Watering and plant protection measures were taken as per the requirement. The plants were removed carefully after 45 days of sowing and observations were recorded and analyzed.

\section{Results and Discussion}

The data in Table 1 revealed the efficacy of castor (R. communis) leaves against M.incognita infesting okra plants in pot conditions. It is evident that shoot length increased in all treatments as compared to untreated check.

Maximum and significantly highest shoot length was recorded in castor leaves @ $25 \mathrm{~g} /$ pot $(30.4 \mathrm{~cm})$ followed by castor leaves @ 20g/pot $(28.5 \mathrm{~cm})$, castor leaves @ 15 g/pot $(24.2 \mathrm{~cm})$, castor leaves @ 10g/pot $(20.9 \mathrm{~cm})$ and castor leaves @ 5 g/pot (20.4 $\mathrm{cm})$.

Results of this study are in conformity with those of Kankam et al., 2015 who found that under screen house condition aqueous extract of Sesamum indicum at $30 \mathrm{~g} / 50 \mathrm{ml}$ suppressed root-knot nematodes better than the control in okra.

Similarly, maximum and significantly highest root weight was recorded in castor leaves @ 25g/pot(30.4 g) followed by Castor leaves @ $20 \mathrm{~g} /$ pot $(28.5 \mathrm{~g})$. This might be due to additional manorial effect of the tested plant leaves which nourishes okra seedlings. At lower dosages of leaves i.e. castor leaves @ 5 g/pot and castor leaves @ $10 \mathrm{~g} /$ pot data on root weight shows that there was no significant difference between these two treatments.

The data pertaining to number of galls shows that all the treatments were effective in reducing number of galls per plant.

The results obtained by Rather and Siddiqui (2007) and Javed et al., (2008) are in line with our findings. Minimum number of galls was recorded in castor leaves $25 \mathrm{~g} / \mathrm{pot}$ (46) followed by castor leaves $20 \mathrm{~g} / \mathrm{pot}$ (53). However there was no significant difference in number of galls in treatments i.e. castor leaves@5 g/pot and castor leaves @ 10 g/pot. 
Table.1 Effect of various dosage of Ricinus communis on growth parameters of okra seedling and development of root-knot nematode, Meloidogyne incognita

\begin{tabular}{|c|c|c|c|c|c|}
\hline Treatments & $\begin{array}{c}\text { Shoot } \\
\text { length }(g)\end{array}$ & $\begin{array}{c}\text { Root } \\
\text { weight }(g)\end{array}$ & $\begin{array}{l}\text { Number of } \\
\text { galls/plant }\end{array}$ & $\begin{array}{c}\text { No of egg } \\
\text { masses/plant }\end{array}$ & $\begin{array}{c}\text { Final nematode } \\
\text { population/200 cc soil }\end{array}$ \\
\hline $\begin{array}{l}\text { Castor leaves@ @ } \\
\text { g/pot }\end{array}$ & 20.4 & 2.71 & $\begin{array}{l}92.00 \\
(9.61) \\
\end{array}$ & $\begin{array}{l}60.00 \\
(7.74) \\
\end{array}$ & $\begin{array}{r}413.00 \\
(20.34) \\
\end{array}$ \\
\hline $\begin{array}{l}\text { Castor leaves@10 } \\
\text { g/pot }\end{array}$ & 20.9 & 2.74 & $\begin{array}{l}87.00 \\
(9.32) \\
\end{array}$ & $\begin{array}{l}56.00 \\
(7.48) \\
\end{array}$ & $\begin{array}{l}384.00 \\
(19.60) \\
\end{array}$ \\
\hline $\begin{array}{l}\text { Castor leaves@ } 15 \\
\text { g/pot }\end{array}$ & 24.2 & 2.99 & $\begin{array}{l}76.00 \\
(8.72)\end{array}$ & $\begin{array}{l}49.00 \\
(7.00)\end{array}$ & $\begin{array}{l}310.00 \\
(17.63)\end{array}$ \\
\hline $\begin{array}{l}\text { Castor leaves @ } \\
20 \mathrm{~g} / \mathrm{pot}\end{array}$ & 28.5 & 3.20 & $\begin{array}{l}53.00 \\
(7.28)\end{array}$ & $\begin{array}{l}37.00 \\
(6.08)\end{array}$ & $\begin{array}{l}265.00 \\
(16.29)\end{array}$ \\
\hline $\begin{array}{l}\text { Castor leaves@ } \\
\text { 25g/pot }\end{array}$ & 30.4 & 3.44 & $\begin{array}{l}46.00 \\
(6.80)\end{array}$ & $\begin{array}{l}29.00 \\
(5.40)\end{array}$ & $\begin{array}{l}224.00 \\
(14.97) \\
\end{array}$ \\
\hline Untreated Check & 19.1 & 2.36 & $\begin{array}{l}103.00 \\
(10.16) \\
\end{array}$ & $\begin{array}{l}63.00 \\
(7.94) \\
\end{array}$ & $\begin{array}{l}477.00 \\
(21.85) \\
\end{array}$ \\
\hline C.D. at $5 \%$ & 2.3 & 0.19 & $(0.34)$ & $(0.32)$ & $(0.78)$ \\
\hline
\end{tabular}

Figures in parenthesis are $V_{\mathbf{n}}$ transformed values

Minimum and least number of egg masses were observed in castor leaves@ $25 \mathrm{~g} / \mathrm{pot}$ (29) followed by castor leaves@ 20 g/pot (37), castor leaves $15 \mathrm{~g} / \mathrm{pot}$ (49). Lower dosages of test plant @ $5 \mathrm{~g} / \mathrm{pot}$ and $10 \mathrm{~g} / \mathrm{pot}$ leaves were found statistically at par with each other. Similar trend was recorded in case of number of egg masses. Similarly, final nematode population reduced in all the treatments as compared to untreated check. Castor leaves@ 25 g/pot was found best for reducing final nematode population of Meloidogyne incognita. Alam et al., 1980 suggested that the involvement of phenolic compounds absorbed systemically by the roots of tomato. Such amended tomato plants might have induced tolerance against rootknot nematode.

\section{References}

Alam, M. M., Ahmad, M., Khan, A. M. 1980. Effect of organic amendment on the growth and chemical composition of tomato, eggplants and chilly and their susceptibility to attack by Meloidoyne incognita. Plant Soil, 57: 231-236.

Jain, R. K., Mathur, K. N., Singh, R. V. 2007. Estimation of losses due to plant parasitic nematodes on different crops in India. Indian Journal of Nematology, 37: 219-220.

Javed, Nazir, El Hassan, Said, Simon, Gowen, Pemproke, B. and Inam-ul-Haq, Muhammed 2008. The potential of combining Pasteuria penetrans and neem (Azadirachta indica) formulations as a management system for root-knot nematodes on tomato. European Jouranal of Nematology, 120: 53-60.

Kankam, F., Nortaa, E. and Sowley, K. and Alhassan, M. 2015. Management of root-knot nematode (Meloidogyne spp.) on okra (Abelmoschus esculuntus (L.) Moench) with aqueous sesame seed extract. International Journal of Agronomy and Agricultural Research, 6(4): 24-31.

Rather, M. A., and Siddiqui, M. A. 2007. Neem for the control of root-knot nematode infecting tomato. Indian Journal of Nematology, 37(1): 81-82.

Shurtleff, M.C., and C.W. Averre 2000. 
Diagnosing plant disease caused by plant parasitic nematodes. The American Phytopathological Society, pp: 187.

Singh, S.K., and R. K. Khurma 2007. Susceptibility of six tomato cultivars to the root-knot nematode Meloidogyne incognita. The South Pacific Journal of
Natural Sciences 13: 73-77. Srivastava, D.S., M. Sehgal, A. Kumar, S. Verma, B.K. Dwivedi and S.P. Singh. 2012. Plant-parasitic nematodes associated with tomato and okra fields of Allahabad, Uttar Pradesh, India. Pakistan Journal of Nematology, 30 (2): 157-167.

\section{How to cite this article:}

Gurpreet Singh, Neeraj, K.K. Verma and Sewak Ram. 2017. Effect of Various Dosages of Castor (Racinius communis) Leaves on Okra (Abelmoschus esculentus) Under Screen House Conditions. Int.J.Curr.Microbiol.App.Sci. 6(8): 3384-3387. doi: https://doi.org/10.20546/ijcmas.2017.608.404 